\title{
Kvalita kalů a odpadů z domovních a malých ČOV a možnosti jejich využití v zemědělství
}

\section{MILOŠ ROZKOŠNÝ, HANA HUDCOVÁ, MIROSLAV PLOTĚNÝ, RADEK NOVOTNÝ, JANA MATYSÍKOVÁ}

Klíčová slova: kal - sediment - kompost - septik - usazovací nádrž - domovní ČOV - anaerobní ČOV - kořenová ČOV - stabilizační nádrž

\section{SOUHRN}

Cílem článku je představit dílčí části řešení projektů TA02020128 a TA02021032. Tyto části rešení zpracovávaly problematiku kvality kalů a dalších odpadů z domovních a malých čistíren (do přibližně 1000 EO) využívajících aktivační, anaerobní a extenzivní (tzv. prírodní, nebo také prírodě blízké) procesy čištění, zahrnující i kořenové čistírny s vertikálními nebo horizontálními filtry a stabilizační nádrže. Tyto čistírny se uplatňují pro čištění komunálních odpadních vod také v České republice, a to pro zdroje velikosti od jednotlivých domů až po obce do 2000 EO. Výzkumné práce zahrnovaly monitoring, vzorkování a analýzy kalů různě odvodněných a stabilizovaných. Dále monitoring a analýzy ostatních odpadů produkovaných na sledovaných ČOV, z objektů mechanického předčištění, kořenových filtrů (vegetace makrofyt, filtrační materiál kolmatovaný kalem) a ze stabilizačních nádrží (sedimenty, vegetace makrofyt). Prezentovány jsou výsledky analýz vzorků kalů a dalších materiálů z několika ČOV velikosti do přibližně 800 EO z období 2006 až 2014 a výsledky pokusného kompostování těchto materiálů.

\section{ÚVOD}

Cílem článku je představit dílčí části řešení projektů TA02020128 a TA02021032 (informace o projektech jsou dostupné na webových stránkách např. www. vuv.cz). Prezentovaná část řešení zpracovává problematiku kvality kalů a dalších odpadů z domovních a malých čistíren (do přibližně 1000 EO) využívajících aktivační, anaerobní a extenzivní (tzv. prírodní nebo také prírodě blízké) procesy čištění, zahrnujíci i kořenové čistírny s vertikálními nebo horizontálními filtry a stabilizační nádrže. Tyto čistírny se uplatňuji pro čištění komunálních odpadních vod také v České republice, a to pro zdroje velikosti od jednotlivých domů až po obce do 2000 EO. Prezentovány jsou výsledky analýz vzorků kalů a dalších materiálů z ČOV z období 2006 až 2014 a výsledky pokusného kompostování těchto materiálů.

Při použití kalu ke hnojení pưdy je třeba věnovat pozornost možné kontaminaci půdy, podzemní, popř. povrchové vody a ovzduší. Vyloučení kontaminace pưdy a rostlin na ní pěstovaných Ize dosáhnout dodržením koncentračních limitů kontaminujících látek $v$ kalu. V České republice je $v$ platnosti vyhláška č. 382/2001 Sb., kde vedle technických a organizačních podmínek aplikace jsou vymezeny kvalitativní ukazatele, jejichž dodržení je nezbytné pro eliminování negativních účinkư kalu vlivem př́tomnosti kontaminantů. Dưležitým ukazatelem pro př́padnou aplikaci, zejména kvůli okamžité možnosti kontaminace, je mikrobiální kontaminace kalů. Proto jsou zmíněnou vyhláškou stanoveny i dvě kategorie kalů z hlediska jejich mikrobiální kontaminace a použitelnosti v zemědělství. Př́pustné pro zemědělskou aplikaci jsou jen stabilizované kaly.
Stabilizace kalů, anaerobní i aerobní, vychází z technických parametrů při tomto zpracování - u anaerobní stabilizace z doby zdržení kalu ve fermentoru a teploty, priččmž technický stupeň vyhnití lze hodnotit z úbytku organické hmoty. Je všeobecně známo, že hygienické vlastnosti kalu se jeho stabilizací výrazně zlepšují, přesto však ani dokonale stabilizovaný kal není materiálem zcela nezávadným [1]. Na úrovni Evropské unie je platná směrnice pro použití kalů v zemědělství [2]. Z hlediska procesu hygienizace patří mezi důležité místní předpisy technická norma TNV 758090 [3].

\section{METODIKA}

V období 2006 až 2014 proběhlo vzorkování kalů objektů mechanického předčištění extenzivních (kořenových) ČOV, sedimentů dočištovacích nádrží extenzivních ČOV, kolmatovaných filtračních materiálů kořenových filtrů a biomasy makrofyt.

Z extenzivních ČOV byly sledovány dvě domovní kořenové čistírny, projektované pro zatížení 4 EO a 20 EO, a dvě komunální čistírny s projektovým zatížením 200 a 800 EO, napojené na jednotné kanalizační sítě [4].

\section{Technologická linka kořenových Čov:}

1. ČOV 800 EO - štěrbinová nádrž (obr. 2) jako objekt mechanického předčištění, navazující kořenové filtry horizontální s podpovrchovým kontinuálním prouděním a dočištovací stabilizační nádrž;

2. ČOV 200 EO - usazovací nádrž podélnou prizmatického tvaru s boční vyhnívací komorou (obr. 3), navazující kořenové filtry horizontální s podpovrchovým kontinuálním prouděním a dočištovací stabilizační nádrž. Návrhové parametry jsou obvyklé těmto systémům [5]. Napojení ČOV na jednotné kanalizační sítě znamená vnos smyvů ze střešních konstrukcí, z komunikací a dalších zpevněných ploch. Tyto smyvy obsahuji určité množství prachu a dalších pevných částic a mohou být zatíženy těžkými kovy a dalšími polutanty [6-8].

Technologická linka obou domovních kořenových ČOV zahrnuje biologický septik (obr. 4) jako objekt mechanického předčištění a navazující kořenový filtr horizontální s podpovrchovým kontinuálním prouděním. Na obě čistírny jsou napojeny pouze splaškové vody produkované čtyřmi obyvateli v prvním př́padě (ČOV pro 4 EO) a deseti obyvateli ve druhém prípadě (ČOV pro 20 EO).

Druhá čistírna byla dimenzována na průměrné zatížení až 20 EO, z důvodu víkendových a prázdninových společenských a kulturních akcí v areálu objektu.

$\checkmark$ rámci projektu TA02021032 byl vyvinutý inovovaný septik (obr. 5), který byl také sledován v poloprovozním režimu.

Druhou skupinu sledovaných čistíren odpadních vod tvořily čistírny anaerobně-aerobní typu Anacomb s návrhovým zatížením od 5 EO do 200 EO $[9,10]($ obr. 1). Jedná se o typ tzv. „balených“ (vestavných) čistíren kombinujících 
sekci čištění vody v anaerobních podmínkách a sekci čištění vody s provzdušováním, tedy sekci typickou pro aktivační čistírny (obr. 1).

Vzorky kalů byly odebírány časově jako bodové, ale prostorově směsné. Vzorky byly odebírány z kalové sekce anaerobních a aktivačních ČOV. U extenzivních ČOV byly odebírány z objektů mechanického předčištění (vyhnívacích prostor štěrbinových usazovacích nádrží, prostor septiků a akumulačních prostor lapáků písku). Vzorky sedimentů z nádrží byly odebírány také jako časově bodové, ale prostorově směsné, a to pomocí pístového odběráku. Vzorky byly umístěny do vzorkovnice z PE a v chladnu přepraveny do laboratoře. V laboratoři byly vzorky homogenizovány, lyofilizovány a dále zpracovány k analýzám - stanovení sušiny, ztráty žíháním, makroelementy ( $\mathrm{Ca}, \mathrm{Mg}, \mathrm{K}, \mathrm{Na}$ $\mathrm{Mn}, \mathrm{Fe}$ ), těžké kovy (tabulka 2 a 4), ukazatele mikrobiálního znečištění fekální koliformní bakterie a enterokoky, obsah dusíku a fosforu. Analýzy byly prováděny podle akreditovaných postupů. Vzorky materiálu kolmatovaného uniklým kalem byly odebírány z kořenových filtrů jako časově a prostorově bodové Vzorky byly odebírány z povrchu (vrstva 0-10 cm) a z hloubky (vrstva 30-40 cm) vždy v hlavní čistící zóně, mimo rozdělovací a sběrné zóny s hrubším kamenivem. Pro stanovení nutrientů, makroelementů a rizikových prvků byla separována frakce pod $0,063 \mathrm{~mm}$. Vzorky biomasy byly sbírány $v$ prípadě makrofyt kosením ze čtverce $0,25 \times 0,25 \mathrm{~m} v$ průběhu celého roku. Po odběru byla biomasa vysušena a dále analyzována.
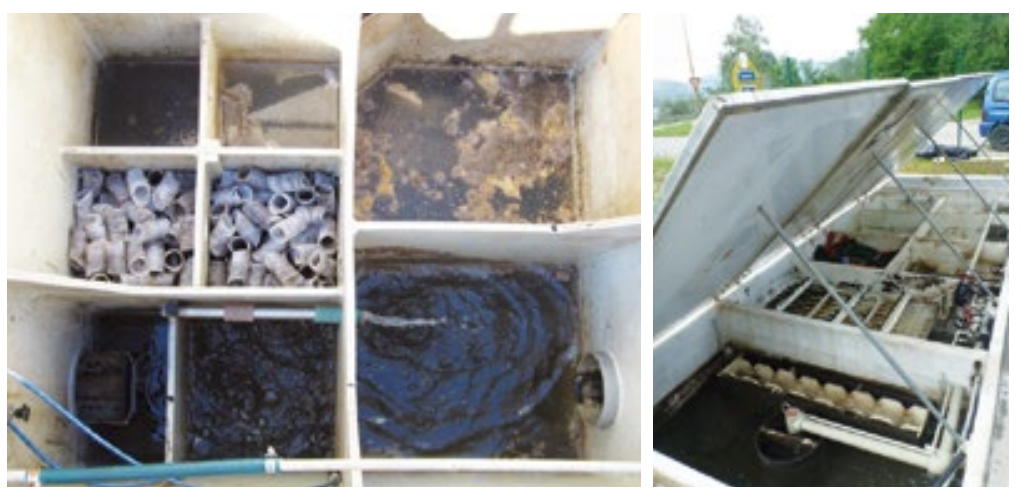

Obr. 1. Pohled na jednotlivé sekce anaerobně-aerobních ČOV (vlevo pro 5 EO, vpravo pro $200 \mathrm{EO})$

Fig. 1. View of individual sections of anaerobic-aerobic WWTP (left WWTP 5 p. e., right WWTP 200 p. e.)

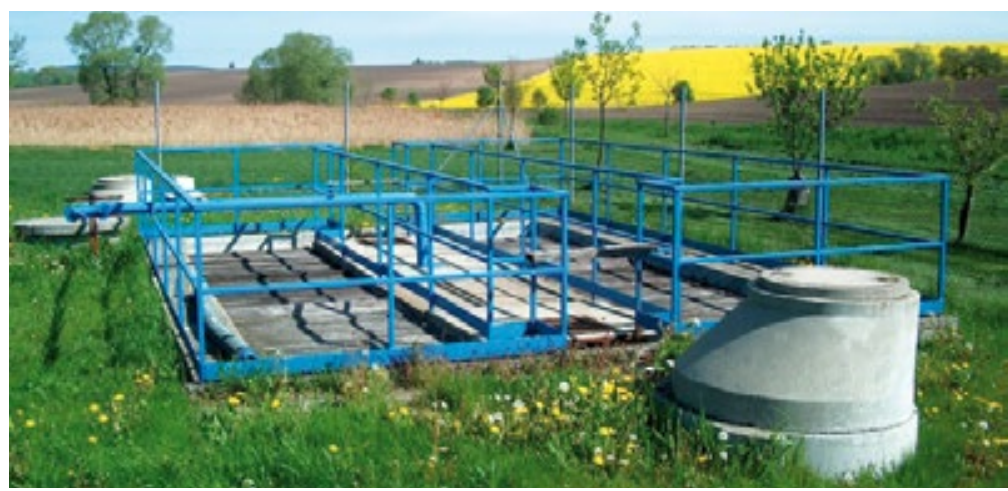

Obr. 2. Štěrbinová usazovací nádrž komunální kořenové ČOV

Fig. 2. Slot (Imhoff) settling tank used as a part of municipal constructed wetland WWTP
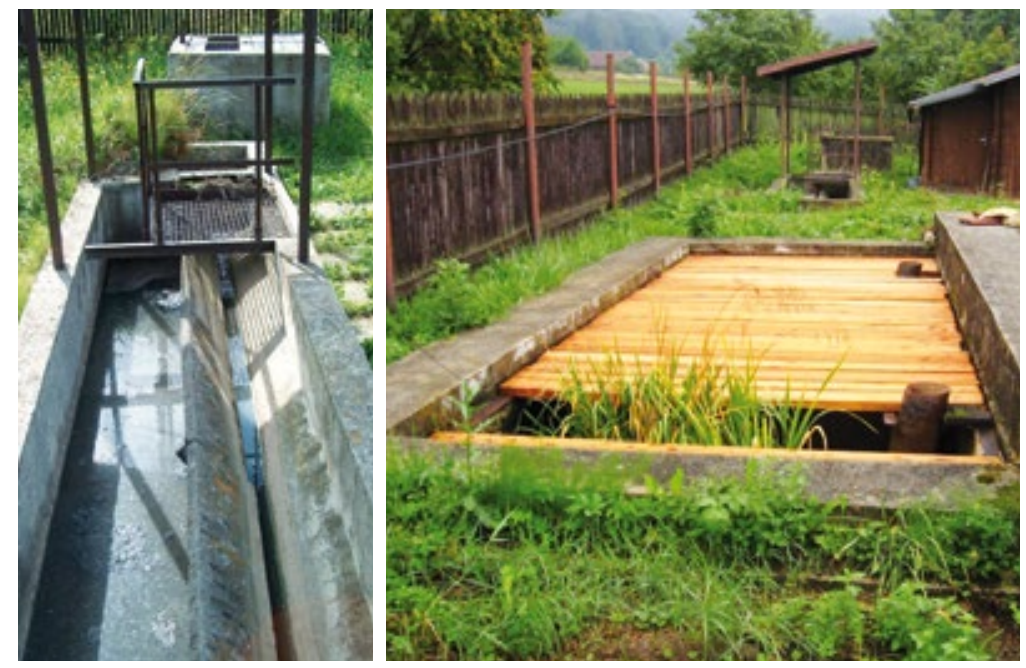

Obr. 3. Štěrbinový lapák písku (vlevo) a pohled na usazovací nádrž s boční vyhnívací komorou (vpravo) komunální kořenové ČOV

Fig. 3. Slot sand trap (left) and a view of settling tank with lateral digestion chamber (right) used as a part of municipal constructed wetland WWTP

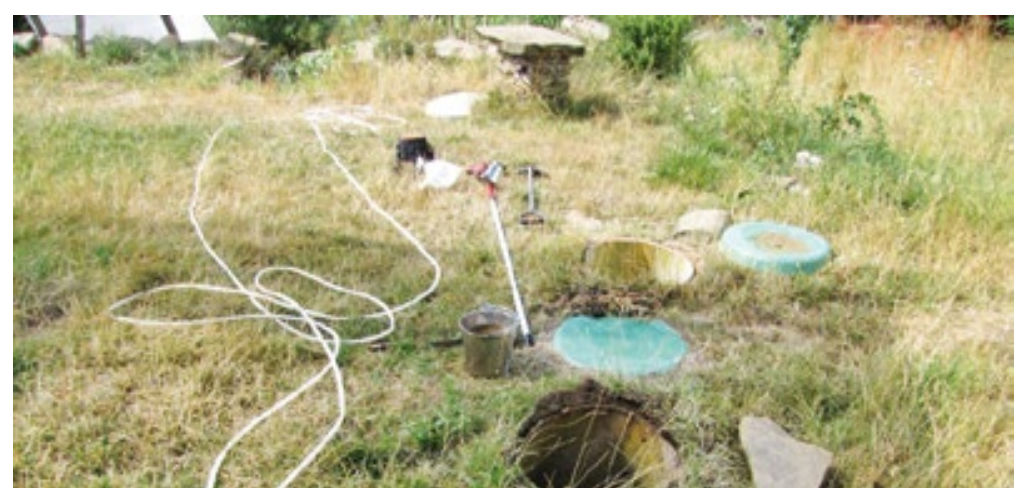

Obr. 4. Příklad sledovaného biologického vícekomorového septiku domovní kořenové ČOV - umístění na pozemku, prístupové otvory

Fig. 4. An example of multi-compartment biological septic tank of a household constructed wetland WWTP - situation at the land, access holes
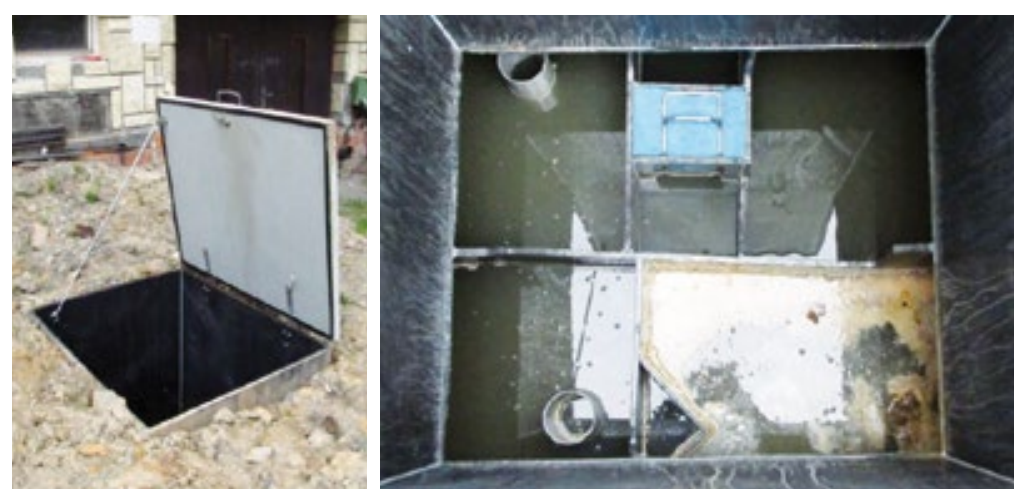

Obr. 5. Př́klad sledovaného biologického vícekomorového septiku vyvinutého v rámci projektu TA02021032 Anasep - umístění na pozemku, pohled do jednotlivých sekcí během provozu

Fig. 5. An example of multi-compartment biological septic tank developed within the research project TA02021032 Anasep - situation at the land, view of individual compartments during operation 


\section{VÝSLEDKY}

\section{Vyhodnocení vzorků kalů a sedimentů z extenzivních (kořenových) ČOV}

S výjimkou jednoho vzorku se zvýšeným obsahem mědi nebylo v celém období sledování 2006 až 2014 zjištěno prekročení obsahu rizikových prvků (těžkých kovů) a látek (PCB, AOX) z hlediska vyhlášky č. 382/2001 Sb. (limity pro těžké kovy jsou uvedeny v tabulce 2). Obsah rizikových prvků ve vzorcích kalů z usazovacích nádrží kořenových čistíren byl následující: $5-9$ mg/kg As, 0,1-0,9 mg/kg Cd, $32-54 \mathrm{mg} / \mathrm{kg} \mathrm{Cr}, 62-586 \mathrm{mg} / \mathrm{kg} \mathrm{Cu}, 0,1-0,7 \mathrm{mg} / \mathrm{kg} \mathrm{Hg}, 24-36$ mg/kg Ni, 18-55 mg/ kg Pb, 165-1 120 mg/kg Zn. Rozsah obsahu AOX byl zjištěn v rozmezí 10-152 mg/ kg (limit dle vyhlášky č. 382/2001 Sb. je 500 mg/kg). Rozsah obsahu PCB byl zjištěn $\vee$ rozmezí 0,01-0,28 mg/kg (limit dle vyhlášky č. 382/2001 Sb. je 0,6 mg/kg). Ve vzorcích sedimentů z dočištovacích nádrží byl zjištěn menší podíl organických spalitelných látek (o přibližně 50 až 70 \%) než v kalech z předčištění. Také je patrný úbytek obsahu mědi, zinku a PCB žrejmě v souvislosti s jejich dobrou akumulací nejen do kalu, ale i do makrofytní vegetace kořenových filtrů [11]. Sediment nádrže za ČOV pro 200 EO byl výrazně méně zatížený než sediment z nádrže za ČOV pro 800 EO. Detailní údaje k obsahu rizikových prvků obou nádrží publikovali Rozkošný a Sedláček [4]. Analýzy mikrobiálního znečištění kalů a sedimentů (enterokoky, termotolerantní koliformní bakterie) neprokázaly nadlimitní zatižzení, vzorky vyhovovaly limitům stanoveným vyhláškou č. 382/2001 Sb. Množství fekálních koliformních bakterií bylo zjištěno $v$ kalech $v$ rozpětí hodnot $1 \times 10^{3}-1 \times 10^{5}$ $\mathrm{KTJ} / \mathrm{g}$ sušiny. Množství enterokoků bylo zjištěno $v$ rozmezí $1 \times 10^{5}-9 \times 10^{5} \mathrm{KTJ} / \mathrm{g}$ sušiny. Prítomnost salmonel nebyla zjištěna. Ve vzorcích sedimentů dočištovací nádrže ČOV pro 800 EO bylo zjištěno množství fekálních koliformních bakterií $\checkmark$ rozmezí $0-6 \times 10^{2} \mathrm{KTJ} / \mathrm{g}$ sušiny, enterokoků $0-1 \times 10^{3} \mathrm{KTJ} / \mathrm{g}$ sušiny. Mikrobiální koncentrace je tedy výrazně nižší než v prípadě kalů z předčištění a prakticky splňuje limity I. kategorie kalů podle zmíněné vyhlášky a v případě těžby je možné je aplikovat obecně na zemědělské pozemky.

\section{Vyhodnocení vzorků kalů ze septiků domovních extenzivních (kořenových) ČOV}

Obsah rizikových prvků ve vzorcích kalů ze septiků domovních kořenových čistíren byl následující: 2-4 mg/kg As, 1-1,5 mg/kg Cd, 8-43 mg/kg Cr, 128-161 mg/kg $\mathrm{Cu}, 0,3-0,6$ mg/kg Hg, 10-28 mg/kg Ni, 8-14 mg/kg Pb, 550-1100 mg/kg Zn. Vzorky měly sušinu3-6\% aztrátu žíháním 60-85\%. Obsah dusíku bylv rozmezí20-30 g/kg sušiny a obsah fosforu 5-14 g/kg sušiny. Složením tedy kaly ze septiků prakticky rádově odpovídají složení kalů z balených ČOV kategorie do 10 EO (tabulky 1 a 2). Mikrobiální znečištění nebylo z důvodu finančních prostředků provedeno.

\section{Vyhodnocení vzorků kalů z aktivačních a anaerobních ČOV typu Anacomb}

Obsahy těžkých kovů ve všech vzorcích kalů z uvedených ČOV nepřekračovaly limitní hodnoty stanovené pro využití kalů v zemědělství (tabulka 2). Výjimkou byl kal z jedné ČOV kategorie do 200 EO s nadlimitním obsahem zinku (tabulka2). Kal z jiné ČOV do 200 EO se v koncentraci zinku bližil stanovenému limitu. Množství kovů a makroelementů v kalech se lišilo také podle typu vod napojených na jednotlivé ČOV, protože do části z nich byly napojeny také menší prưmyslové provozovny. U kalů ČOV kategorie do 10 EO byly zjištěny menší obsahy chromu, arsenu, rtuti, niklu, olova a zinku. $\vee$ tabulce 1 jsou uvedeny obsahy dusíku, fosforu a makroelementů. Sušina kalů a obsah spalitelných organických látek se u obou kategorií ČOV pohybovaly v prakticky stejném rozmezí.
Tabulka 1. Obsah makroelementů a nutrientů ve vzorcich pevných matric anaerobnè-aerobnich ČOV Anacomb (hodnoty uvedeny jako: min-max/průměr)

Table 1. Contents of macroelements and nutrients in samples of solid matrices of the anaerobic-aerobic WWTPs Anacomb (range of min-max values/average value of the whole data set)

\begin{tabular}{lll}
\hline $\begin{array}{l}\text { Parametr } \\
\text { (g/kg sušiny) }\end{array}$ & ČOV do 10 EO & ČOV do 200 EO \\
\hline $\mathrm{N}$ & $18,8-50,4 / 29,6$ & $23,5-57 / 37,7$ \\
\hline $\mathrm{P}$ & $2,9-12,6 / 7,5$ & $5,8-35,1 / 13,2$ \\
\hline $\mathrm{K}$ & $0,64-2,1 / 1,27$ & $2,0-6,7 / 3,5$ \\
\hline $\mathrm{Na}$ & $0,65-1,41 / 1,1$ & $1,0-2,4 / 1,6$ \\
\hline Fe & $2,2-8,8 / 4,1$ & $2,8-18,3 / 10,0$ \\
\hline Mn & $0,04-0,12$ / 0,08 & $0,04-0,3 / 0,16$ \\
\hline Al & $1,7-9,9 / 4,7$ & $1,3-26,7 / 14,9$ \\
\hline Sušina (\%) & $2-14 / 9$ & $5-12$ / 9 \\
\hline Ztráta žíháním (\%) & $53-92 / 80$ & $53-88$ / 71 \\
\hline
\end{tabular}

Oproti kalům anaerobně stabilizovaným z objektů mechanického předčištění extenzivních ČOV obsahovaly kaly všech balených čistíren kategorie do 10 EO výrazně vyšší množství mikroorganismů (ukazatele enterokoky a fekální koliformní bakterie). Množství fekálně koliformních bakterií se pohybovalo $\vee$ rozpětí $1 \times 10^{5}-3,7 \times 10^{7} \mathrm{KTJ} / \mathrm{g}$ sušiny a množství enterokoků $\vee$ rozpětí $2,5 \times 10^{4}-1,6 \times 10^{7} \mathrm{KTJ} / \mathrm{g}$ sušiny. Pro prípadné využití kalů $v$ zemědělství by bylo nutné jejich další zpracování, nebo odvoz ke zpracování v rámci kalového hospodářství větší ČOV, což se u všech sledovaných lokalit provádí.

Tabulka 2. Obsah rizikových prvků a sloučenin ve vzorcích pevných matric anaerobně-aerobnich ČOV Anacomb (hodnoty uvedeny jako: min-max/prưměr)

Table 2. The content of hazardous elements and compounds in samples of solid matrices of the anaerobic-aerobic WWTPS Anacomb (range of min-max values/average value of the whole data set)

\begin{tabular}{llll}
\hline Parametr & ČOV & ČOV & Limitní \\
$(\mathrm{mg} / \mathrm{kg}$ sušiny) & do 10 EO & do 200 EO & hodnoty
\end{tabular}

(vyhl. č. 382/

$2001 \mathrm{Sb}$.

\begin{tabular}{llll}
\hline As & $0-2,8 / 1,9$ & $1-10 / 4,6$ & 30 \\
\hline $\mathrm{Cd}$ & $0,4-3,2 / 1,5$ & $0,4-2,3 / 1,1$ & 5 \\
\hline $\mathrm{Cr}$ & $12,3-24,1 / 17,9$ & $21,8-96,3 / 53,1$ & 200 \\
\hline $\mathrm{Cu}$ & $106-463 / 193$ & $122-197 / 154$ & 500 \\
\hline $\mathrm{Hg}$ & $0,19-1,77 / 0,79$ & $0,54-1,5 / 1,1$ & 4 \\
\hline $\mathrm{Ni}$ & $5,3-17 / 10,8$ & $8,6-31,5 / 20,1$ & 100 \\
\hline $\mathrm{Pb}$ & $6,2-21,9 / 12,2$ & $10,5-39,3 / 21,9$ & 200 \\
\hline $\mathrm{Zn}$ & $505-1260 / 853$ & $855-3580 / 1712$ & 2500 \\
\hline
\end{tabular}




\section{Filtrační materiál kořenových filtrů}

Změny filtračních materiálů kořenových filtrů podrobně zkoumala např. Hyánková [12], Švehla a kol. [11], Suchý a kol. [13] apod. Autoři uvádí změny pórovitost a hydraulické vodivosti filtračních materiálů $v$ důsledku kolmatace $v$ čase. Procentní podíl kalu $v$ sušině filtračního materiálu se pohyboval $v$ jednotkách procent. $V$ částech kořenových filtrů několika ČOV nejvíce zasažených kolmataci byly zjištěny hodnoty 10 až $16 \%$ kalu v sušině materiálu. Se vzdáleností od nátoku vod do kořenových filtrů podíl kalu klesal, a to u všech ČOV sledovaných v mnoha studiích výše uvedenými autory. Tyto poznatky potvrzují také průzkumy filtračních materiálů kořenových filtrů ČOV Dražovice, Hostětín, Myslibořice, Olší nad Oslavou a Pavlínov prováděné Vúv TGM, v.vi.., Brno v letech 2008 až 2012. Podíl spalitelných organických látek (ztráta žíháním) $v$ sušině filtračních materiálů obsahujících jednotky procent kalu byl zjištěn do $3 \%$. V roce 2012 byly odebrány vzorky z kořenových filtrů ČOV Dražovice pro zjištění obsahu nutrientů, makroelementů a rizikových prvků. Ztráta žíháním vzorků z oblasti nátokových zón činila 13 až $19 \%$, z oblasti odtokových zón do $5 \%$. Obsah vybraných prvků ve frakci pod 0,063 mm byl následující: celkový dusík 19-36,4 g/kg sušiny, celkový fosfor 2,5-8,5 g/kg, Na 0,5-1,1 g/kg, K 3-10 g/kg, Ca 19-85 g/kg, Mg 4,9-8,6 g/kg, Al 12,6-35,2 g/kg, Fe 8-27 g/kg, Mn 0,27-0,37 g/kg sušiny. Obsah rizikových prvků ve stejné frakci byl v následujících rozmezích: As 4,9-9,9 mg/kg, Cd 0,5-1,1 mg/kg Cr 20,3-95,3 mg/kg, Cu 123-453 mg/kg, Hg 0,18-0,64 mg/kg, Ni 26,9-37,2 mg/kg, $\mathrm{Pb} 13,6-42,7 \mathrm{mg} / \mathrm{kg}, \mathrm{Zn} 679-310 \mathrm{mg} / \mathrm{kg}$ sušiny. Množství rizikových prvků tedy opět nepřekračuje limitní hodnoty dané vyhláškou o použití kalů v zemědělství a všechny zjištěné údaje odpovídají složení vzorků kalu z let 2006 až 2012 odebraných z usazovací nádrže, což bylo možné prèdpokládat. Suchý a kol. [13] uvádí ve vzorcích separovaných kalů z kolmatovaných filtračních materiálů kořenových filtrů sedmi kořenových čistíren stáří 2-6 let následující průměrné hodnoty: cel-

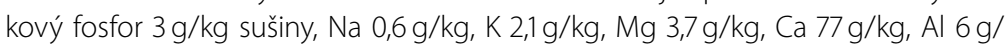
kg, Fe 5 g/kg, Mn 0,08 g/kg, As 2 mg/kg, Cd 0,2 mg/kg, Cr 40,2 mg/kg, Cu 18,5 mg/ kg, Hg 0,08 mg/kg, Ni 14,9 mg/kg, Pb 15,5 mg/kg a Zn 273 mg/kg. Zjištěné hodnoty tedy rádově odpovídají námi provedeným rozborům. Mikrobiální zatížení kolmatovaných materiálů bylo zjištěno nižší než v případě vlastních kalů z mechanic-

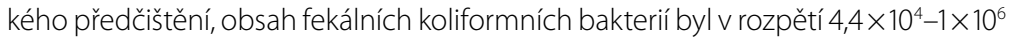
$\mathrm{KTJ} / \mathrm{g}$ sušiny, obsah enterokoků $7,6 \times 10^{3}-9 \times 10^{5} \mathrm{KTJ} / \mathrm{g}$ sušiny. Lze předpokládat, že po vyplavení kalu objektů mechanického předčištění a jejich sedimentace ve filtračních materiálech kořenových filtrů dochází k jejich stabilizaci, a to $v$ aerobních až anaerobních podmínkách podle tlouštky vrstvy naplaveného materiálu.

\section{Biomasa makrofyt z povrchu kořenových filtrů}

Dalším odpadem produkovaným provozem kořenových čistíren odpadních vod je biomasa makrofytní vegetace, kterou jsou osázeny tzv. kořenové filtry. Provozní přistupy k údržbě této vegetace jsou různé, od stavu, kdy není biomasa sklízena prakticky od začátku provozu čistírny, pres každoroční spalování v jarních obdobích přímo na povrchu filtrů, až po kosení a sklízení v různých obdobích roku (během vegetačních sezon, na podzim, ke konci zimy) v rưzném časovém intervalu (každoročně, jednou za několik let). S vývojem aplikace této čistírenské technologie v České republice je možné konstatovat, že pravidelné sklízení vegetace makrofyt vede k její lepší regeneraci (bez sklízení postupem času vegetace řídne, mění se její složení, dochází k náletu a rozvoji druhotné vegetace druhů náročných na živiny), lepší kontrole povrchu filtrů a nedochází k akumulaci biomasy z rozkladu staré vegetace na povrchu filtrů. Množství akumulované hmoty bylo zjištěno u kořenových filtrů bez sklízení vegetace po dobu cca 10 let v rozmezí 2 až $4 \mathrm{~cm}$. Charakter materiálu se bliží kompostu (vlastní pozorování autorského týmu). Výsledky rozborů vzorků biomasy rákosu (Phragmites australis) a chrastice (Phalaris arundinacea), tedy dvou základních druhů využívaných prìi realizaci kořenových ČOV v České republice, uvádí podrobně Vymazal a kol. [14] a Vymazal a kol. [15].

\section{NAKLÁDÁNÍ SE SLEDOVANÝMI MATERIÁLY}

V roce 2012 bylo zahájeno pokusné zpracování odpadů z extenzivních ČOV (kaly, kolmatovaný filtrační materiál, makrofytní vegetace kořenových filtrů) kompostováním. Postupně bylo připraveno několik sad pokusných kompostů s využitím odpadních materiálů extenzivních ČOV (stabilizovaný kal, filtrační materiál kolmatovaný uniklým kalem a obohacený zbytky po rozkladu biomasy vegetace, sklizená makrofytní vegetace z kořenových filtrů a biomasa z kosení trávníků $\vee$ areálu ČOV). $V$ roce 2014 tyto pokusy zaměřené na extenzivní ČOV byly rozšířeny o další typy ČOV a jimi produkované odpady (kaly z procesu čištění) u zdrojů do 1000 EO. V tabulce 3 až 5 jsou uvedeny výsledky analýz konečných produktů (kompostů) z procesu kompostování odpadů a kalů produkovaných komunální kořenovou ČOV pro 800 EO po ukončení dvou sérií pokusů.

\section{LEGENDA K OZNAČENÍ VZORKŮ K5 AŽ K8}

K5 - biomasa + filtrační materiál s kalem uniklým z usazovací nádrže (akumulace kalu po dobu cca 13 let) - horní polovina kompostéru

K6 - biomasa + filtrační materiál s kalem uniklým z usazovací nádrže (akumulace kalu po dobu cca 13 let) - dolní polovina kompostéru

K7 - biomasa + kaly z objektů mechanického předčištění - horní polovina kompostéru

K8 - biomasa + kaly z objektů mechanického předčištění - dolní polovina kompostéru

Tabulka 3. Obsah vybraných nutrientů ve vzorcích kompostů z extenzivní (korenové) ČOV (hodnoty uvedeny jako: 1. série / 2. série)

Table 3. Content of nutrients in samples of composts from constructed wetland WWTP (st batch $/ 2^{\text {nd }}$ batch)

\begin{tabular}{lllll}
\hline $\begin{array}{l}\text { Parametr } \\
\text { (g/kg sušiny) }\end{array}$ & K5 & K6 & K7 & K8 \\
\hline $\mathrm{N}$ & $1,61 /-$ & $0,48 /-$ & $1,48 /-$ & $0,33 /-$ \\
\hline $\mathrm{P}$ & $8,72 / 8,41$ & $2,43 / 4,78$ & $4,11 / 2,69$ & $2,95 / 1,76$ \\
\hline Sušina (\%) & $54,2 / 47,2$ & $92,1 / 68,7$ & $68,6 / 80,4$ & $95,7 / 88,5$ \\
\hline Ztráta žíháním (\%) & $32,9 / 29,1$ & $9,80 / 13,1$ & $26,2 / 8,9$ & $6,99 / 10,5$ \\
\hline
\end{tabular}

Tabulka 4. Obsah těžkých kovů ve vzorcích kompostů z extenzivní (kořenové) ČOV (hodnoty uvedeny jako: 1. série/2. série)

Table 4. Content of heavy metals in samples of composts from constructed wetland WWTP (pt batch / $2^{\text {nd }}$ batch)

\begin{tabular}{lllll}
\hline $\begin{array}{l}\text { Parametr } \\
\text { (mg/kg sušiny) }\end{array}$ & K5 & K6 & K7 & K8 \\
\hline $\mathrm{As}$ & $13,4 / 12$ & $7,9 / 8,6$ & $9,4 / 7,4$ & $3,9 / 3,6$ \\
\hline $\mathrm{Cd}$ & $1,31 / 1,1$ & $0,32 / 0,71$ & $0,68 / 0,24$ & $0,28 / 0,15$ \\
\hline $\mathrm{Cr}$ & $105 / 77,9$ & $44,4 / 54,8$ & $55,8 / 45,8$ & $22,6 / 27,2$ \\
\hline $\mathrm{Cu}$ & $395 / 385$ & $92,3 / 306$ & $243 / 108$ & $1620 / 104$ \\
\hline $\mathrm{Hg}$ & $0,575 / 0,644$ & $0,132 / 0,406$ & $0,245 / 0,118$ & $0,101 / 0,139$ \\
\hline $\mathrm{Ni}$ & $43,0 / 52,3$ & $25,6 / 37,1$ & $31,6 / 31,6$ & $17,9 / 19,8$ \\
\hline $\mathrm{Pb}$ & $44,3 / 56,7$ & $20,6 / 40,3$ & $28,0 / 25,7$ & $25,1 / 24,8$ \\
\hline $\mathrm{Zn}$ & $2130 / 1780$ & $314 / 1200$ & $887 / 311$ & $309 / 347$ \\
\hline
\end{tabular}


Tabulka 5. Mikrobiologické ukazatele ve vzorcích kompostů z extenzivní ČOV (hodnoty uvedeny jako: 1. série/2. série)

Table 5. Microbial contamination of the samples of composts from constructed wetland WWTP (15t batch / $2^{\text {nd }}$ batch)

\begin{tabular}{lllll}
\hline $\begin{array}{l}\text { Parametr } \\
\text { (KTJ/g sušiny) }\end{array}$ & K5 & K6 & K7 & K8 \\
\hline Fek. kolif. bakterie & $74 / 0$ & $130 / 0$ & $0 / 0$ & $0 / 0$ \\
\hline Enterokoky & $2340 / 127$ & $11 / 44$ & $1060 / 473$ & $84 / 113$ \\
\hline
\end{tabular}

Jak vyplývá z dlouhodobých sledování kalů z objektů mechanického předčištění extenzivních ČOV, nepřekračuje jejich kontaminace rizikovými prvky a látkami a mikrobiální znečištění limitní hodnoty dané vyhláškou pro použití kalů $v$ zemědělství. Mikrobiální znečištění kalů je však poměrně proměnlivé v závislosti na míre stabilizace. Pro dosažení větší stability míry kontaminace by bylo dobré více hlídat probíhající procesy, případně zvolit mezistupeň stabilizace kalů pred jejich použitím v zemědělství. Podobné zkušenosti ze zahraničí uvádí např. Oleszkiewicz [16] a Uggetti [17]. Jednou z možností je kompostování $[17,18]$. Tento proces přináší pozitivní změny vstupních materiálů a jejich nižší kontaminaci. Možnost uplatnění kalů v zemědělství se však vyvijí v období, kdy provádíme sledování podle dohody mezi provozovateli a zemědělsky hospodařícími subjekty. V obdobích, kdy není zájem ze strany těchto subjektů o kaly, je nutné jejich vyvážení na jiné komunální ČOV s kalovým hospodářstvím, což je i pro provozovatele finančně náročnější.

Kaly z balených ČOV všech kategorií do 200 EO, které byly sledovány, jsou vyváženy obvykle dodavateli ČOV k dalšímu zpracování v rámci kalového hospodářství větších komunálních ČOV. Kaly ze septiků domovních extenzivních (kořenových) ČOV nebyly od zahájení jejich provozu (roky 2010 a 2011) prozatím vyváženy. Prakticky hlavním problémem pro prímou aplikaci kalů z tzv. „balených" ČOV (sledovány vybrané typy ČOV a anaerobními a aerobními sekcemi) $\checkmark$ zemědělství je jejich zjištěná mikrobiální kontaminace. Je tedy nutné kaly odvážet k další stabilizaci a snižení mikrobiální kontaminace.

Výskyt kalů na povrchu kořenových filtrů souvisí s jejich vyplavováním při hydraulickém přetižení ČOV a nebo s jejich bytněním a vyplouváním k hladině, odkud jsou vodou unášeny dále na filtry, v prípadě, že $v$ usazovacím prostoru nejsou dostatečně navržené norné stěny. Vyplavování kalů v obou případech je u štěrbinových nádrží spojeno zřejmě s tím, že nejsou dostatečně prostupné štěrbiny (také v důsledku bakteriálních nárostů) a dochází k usazování kalů v prostoru nad štěrbinami, odkud jsou následně vyplavovány, nebo unikají při bytnění. U jiných typů nádrží a u septiků je př́činou nevhodný návrh konstrukcí objektů, nebo obtižné a nedostatečné odkalování pozorované u nádrží s bočními vyhnívacími komorami, kdy je kal přepouštěn do komor ode dna.

Biomasu makrofyt je možné využít pro kompostování. Naprosto nevhodným způsobem údržby je spalování této vegetace, zejména prímo na povrchu biofiltrů.

Kontaminace sedimentů dočištovacích nádrží nepřekračuje limity pro jejich využití v zemědělství. Mikrobiální kontaminace odebraných vzorků byla velmi nízká. Zjištěné hodnoty umožňují prímé využití v prípadě těžby těchto sedimentů.

\section{ZÁVĚR}

Průzkum způsobů hospodaření s produkovanými odpady sledovaných Čov ukázal, že zatím nejsou zpracovávány jako surovina, pouze stabilizované kaly jsou $v$ některých prípadech využívány pro hnojení zemědělských pozemků. Z tohoto důvodu byly práce zaměřeny na ověření možností kompostování odpadových materiálů a ověření jejich aplikace při pěstování vybraných plodin (výsledky pokusů nebyly k datu zpracování príspěvku kompletní). Prozatímní výsledky kompostování prokázaly výrazné snižení mikrobiálního zatížení odpadů z ČOV a obsah poměrně velkého množství makroelementů využitelných vegetací při aplikaci výsledného produktu kompostování. Pozornost je však nutné věnovat obsahu těžkých kovů, protože ke snížení jejich obsahu kompostováním prakticky nedochází, výsledný obsah je výsledkem poměru míchání jednotlivých složek a při aplikaci je nutné mít informace o obsahu těchto kovů v půdě, kde se předpokládá aplikace kompostů. Je nutné zdůraznit, že biologicky dostupná bude pouze část těchto rizikových prvků. Pro praktickou aplikaci je nutné porovnání s požadavky a limitními hodnotami danými technickou normou k průmyslovým kompostům [19].

\section{Poděkování}

Prezentace byla vytvořena za podpory projektů TA02020128 Výzkum možností optimalizace provozu a zvýšení účinnosti čištěni odpadnich vod z malých obcí pomocí extenzivních technologii a TA02021032 Anaerobní separátor nerozpuštěných látek a nutrientů.

\section{Literatura}

[1] Malý, J. Zneškodňování odpadních látek z malých ČOV. In: Nové poznatky při řešení vegetačních kořenových čistíren. Sborník ze semináře. Brno: VUT FAST ÚVHK, 1998, s. 65-69.

[2] Council of the EU. Council Directive 86/278/EEC on the Protection of the Environment, and in Particular of the Soil, when Sewage Sludge is Used in Agriculture, 1986.

[3] TNV 758090. Hygienizace kalů v čistírnách odpadních vod. ÚNMZ, 2015.

[4] Rozkošný, M. a P. Sedláček. Dočištění odtoků z kořenových čistíren odpadních vod stabilizačními nádržemi. VTEl, roč. 55, č. 1, 2013, s. 7-12. ISSN 0322-8916, príloha Vodního hospodářství, č. 2/2013.

[5] Šálek, J. a V. Tlapák. Prírodní způsoby čištění znečištěných povrchových a odpadních vod. Praha: ČKAIT, $2006,283 \mathrm{~s}$

[6] Hvited-Jacobson, T. and Y.A. Yousef. Highway Runoff Quality, Environmental Impacts and Control. In: Highway Pollution (Hamilton, R. S. and Harrison, R. M., eds). Amsterdam: Elsevier, 1991, p. 165-208.

[7] Sansalone, J.J. Adsorptive infiltration of metals in urban drainage - media characteristics. Sci. Tot. Env., 235, 1999, p. 179-188.

[8] Bäckström, M., S. Karlsson, L. Bäckman, L. Folkeson, and B. Lind. Mobilisation of heavy metals by deicing salts in a roadside environment. Wat. Research, vol. 38, 2004, p. 720-732.

[9] Gašparíková, E. a I. Bodík. Zhodnotenie prevádzky domových čistiarní odpadových vôd. Vodni hospodářství, roč. 54, č. 7, 2004. ISSN 1211-0760.

[10] http://www.bazeny.sk/asio/index.php?l=sk \& s=3 (poslední prístup 12. 10. 2015).

[11] Švehla, J., J. Vymazal, L. Kröpfelová aj. Vybrané stopové prvky v sedimentech kořenových čistíren. In: Monitoring těžkých kovů a vybraných rizikových prvkư při čištění odpadních vod v umělých mokr̆adech (GAČR 206/06/0058). Třeboň: ENKI, 2008, s. 69-77.

[12] Hyánková, E. Vlastnosti filtračního prostředi pro prírodní zpưsoby čištěni odpadních vod. Disertační práce. Brno: ÚVHK FAST VUT, 2005, 86 s., prílohy.

[13] Suchý, V. aj. Odstraňování vybraných rizikových prvků z komunálních odpadních vod do kalu na kořenových čistírnách. Bulletin. Vodňany: VúRH, roč. 45, č. 4, 2009.

[14] Vymazal, J. aj. Trace metals in Phragmites australis and Phalaris arundinacea growing in constructed and natural wetlands. Science of the Total Environment, vol. 380, 2007, p. 154-162.

[15] Vymazal, J. aj. Trace elements in Phragmites australis growing in constructed wetlands for treatment of municipal wastewater. Journal of Ecological Engineering, vol. 35, 2009, p. 303-309.

[16] Oleszkiewicz, J.A. and D.S. Mavinic. Wastewater biosolids: An overview of processing, treatment and management. Journal of Environmental Engineering Science, n. 1, 2002, p. 75-88.

[17] Uggetti, E., I. Ferrer, E. Llorens, D. Güell, and J. García. Properties of Biosolids from Sludge Treatment Wetlands for Land Application. In: Vymazal, J. (ed). Water and Nutrient Management in Natural and Constructed Wetlands. Springer, 2010, p. 9-20, ISBN 978-90-481-9584-8.

[18] Nielsen, S. and N. Willoughby. Sludge treatment and treatment wetlands systems in Denmark. Water and Environmental Journal, vol. 19, 2005, p. 296-305.

[19] ČSN 46 5735. Průmyslové komposty. ÚNMZ. 1991 


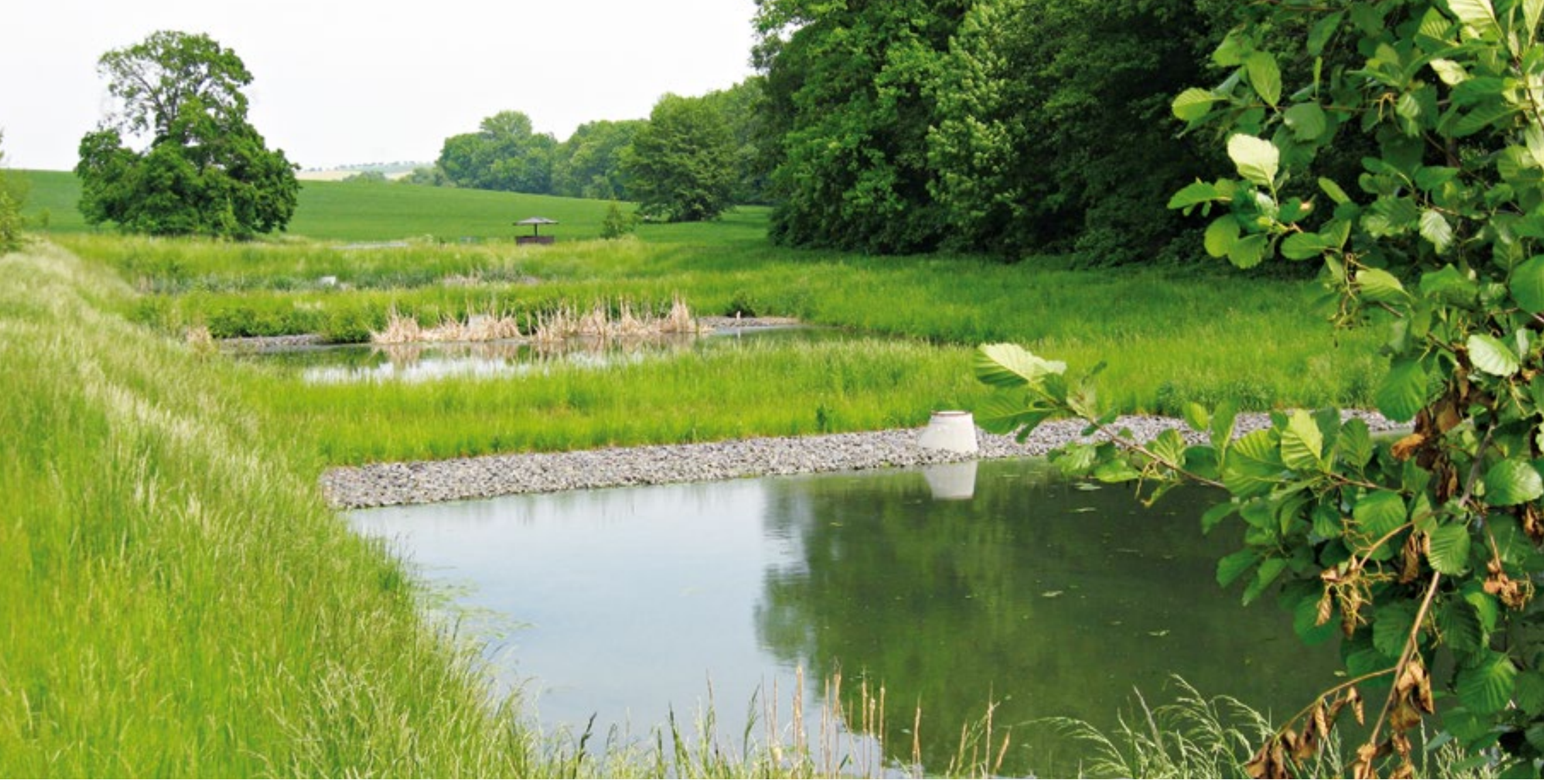

\section{Autoři}

Ing. Miloš Rozkošný, Ph.D.1

凶milos_rozkosny@vuv.cz

Ing. Hana Hudcová',

凶hana_hudcova@vuv.cz

Ing. Miroslav Plotěný ${ }^{2}$

凶mploteny@asio.cz

Ing. Radek Novotný'

凶radek_novotny@vuv.cz

Ing. Jana Matysíková ${ }^{2}$

凶matysikova@asio.cz

'Výzkumný ústav vodohospodářský TGM, v.v.i., pobočka Brno

${ }^{2} \mathrm{ASIO}$, spol.s r. o

${ }^{3}$ Česká zemědělská univerzita v Praze, Fakulta životního prostředí

Přispěvek prošel lektorským řizením.

\section{QUALITY OF SLUDGES AND WASTES FROM HOUSEHOLD AND SMALL WASTEWATER TREATMENT PLANTS AND THEIR UTILIZATION IN AGRICULTURE MANAGEMENT}

\section{ROZKOSNY, M.'; HUDCOVA, H. ${ }^{1,3}$; PLOTENY, M. ${ }^{2}$; NOVOTNY, R. ${ }^{1}$; MATYSIKOVA, J. ${ }^{2}$}

'TGM Water Research Institute, p.r.i., Brno branch

ASIO, Ltd.

${ }^{3}$ Czech University of Life Sciences Prague, Faculty of Environmental Sciences

Key words: sludge - sediment - compost - septic - settling tank household WWTP - anaerobic WWTP - constructed wetland stabilization pond

The aim of this article is to introduce partial sections of the research projects TA02020128 and TA02021032 (Technology Agency of the Czech Republic). These parts of the projects pay attention to the issue of quality of sludge and other wastes produced in wastewater treatment plants (WWTP) using activated sludge process, anaerobic processes (including septics) and extensive (natural) wastewater treatment plants (with horizontal subsurface flow reed-beds), which also include mechanical pre-treatment. The research work covers monitoring and analysis of sludge in different stage of dewatering and digestion. It also covers monitoring and analysis of other wastes produced by the treatment processes in mechanical pre-treatment facilities, reed-beds (macrophyta vegetation, clogged filtration materials) and stabilization ponds (sediments, macrophyta vegetation) built as a part of natural wastewater treatment plants. There are presented results of analysis from a few WWTP up to approx. 800 p.e. from the period 2006-2014 and results of experimental composting of the mentioned materials. 